\title{
Rapid and sensitive detection of canine distemper virus by one-tube reverse transcription-insulated isothermal polymerase chain reaction
}

\author{
Rebecca P Wilkes ${ }^{1 *}$, Yun-Long Tsai ${ }^{2}$, Pei-Yu Lee ${ }^{2}$, Fu-Chun Lee ${ }^{2}$, Hsiao-Fen Grace Chang ${ }^{2}$ \\ and Hwa-Tang Thomas Wang ${ }^{2}$
}

\begin{abstract}
Background: Canine distemper virus (CDV) has been associated with outbreaks of canine infectious respiratory disease in shelters and boarding kennel environments. POCKIT ${ }^{\mathrm{TM}}$ Nucleic Acid Analyzer is a field-deployable device capable of generating automatically interpreted insulated isothermal polymerase chain reaction (iiPCR) results from extracted nucleic acid within one hour. In this study, reverse transcription iiPCR (RT-iiPCR) was developed to facilitate point-of-need diagnosis of CDV infection.

Results: Analytical sensitivity (limit of detection 95\%) of the established CDV RT-iiPCR was about 11 copies of in vitro transcribed RNA per reaction. CDV RT-iiPCR generated positive signals from CDV, but not Bordetella bronchiseptica, canine parvovirus, canine herpesvirus, canine adenovirus 2, canine influenza virus (subtype H3N8), canine parainfluenza virus, and canine respiratory coronavirus. To evaluate accuracy of the established reaction in canine distemper clinical diagnosis, 110 specimens from dogs, raccoons, and foxes suspected with CDV infection were tested simultaneously by CDV RT-iiPCR and real-time RT-PCR. CDV RT-iiPCR demonstrated excellent sensitivity (100\%) and specificity (100\%), compared to real-time RT-PCR.

Conclusions: The results indicated an excellent correlation between RT-iiPCR and a reference real time RT-PCR method. Working in a lyophilized format, the established method has great potential to be used for point-of-care diagnosis of canine distemper in animals, especially in resource-limited facilities.
\end{abstract}

Keywords: Canine distemper virus, Insulated isothermal polymerase chain reaction, iiPCR, Point-of-care diagnosis

\section{Background}

Canine distemper $(\mathrm{CD})$, caused by canine distemper virus (CDV), is a highly contagious and lethal systemic disease in young dogs [1]. This virus infects and produces clinical disease in members of the order Carnivora, including members of the families Canidae (fox, coyote, wolf), Mustelidae (ferret, skunk, badger, mink, weasel, otter, fisher), Procyonidae (raccoon), Felidae (lions, tigers), Ailuridae (red panda), Hyaenidae (hyenas), Ursidae (bear), and Viverridae (palm civet, genets) [2].

CDV is a viral disease of global importance in common and endangered carnivores [3]. CDV contributed to

\footnotetext{
* Correspondence: beckpen@utk.edu

'University of Tennessee College of Veterinary Medicine Clinical Virology Lab, Department of Biomedical and Diagnostic Sciences, University of Tennessee, 2407 River Dr, Rm A205, Knoxville, TN 37996, USA

Full list of author information is available at the end of the article
}

the endangerment of the North American black-footed ferret [4], is an emerging disease in the endangered wild Amur tigers in the Russian Far East [3], and led to the death of 20\% of the Serengeti and Mara lions in the 1990s [5]. The virus also causes disease in non-carnivores, including collared peccaries (Tayassu tajacu) [6], and has recently been detected in macaques (Macaca) in Japan [7] and China [8].

Raccoons have been implicated in the spread of CDV to animals in zoo collections and conservation parks [2], and CDV outbreaks have been documented in raccoons living around a suburban zoo [9]. Therefore, domestic dogs are not the only species at risk following the movement of the distemper virus into a wildlife species. CDV produced mass die-offs of thousands of Caspian seals (Pusa caspica) between 1997 and 2001. The source 
for the epizootic strain is still unknown but thought to be a terrestrial carnivore [10].

CDV, a member of Morbillivirus genus in the Paramyxoviridae family, contains a single-stranded, negativesense genomic RNA, which is around 15,690-nt long $[11,12]$. CDV infection leads to a multi-systemic infection with signs including respiratory, gastrointestinal and neurological disorders. CDV has been classified into several genetic lineages based on diversity among strains from distinct geographic locations. There are 7 major CDV lineages, America-1, America-2, European, European Wildlife, Asia-1, Asia-2, and Arctic like [13], as well as some additional proposed ones that have been more recently discovered, including Asia-3 [14], Asia-4 [15], Africa [13], Europe/South America 1 (European), South America 2, and South America 3 [16-19]. The Onderstepoort and Snyder Hill strains, members of the America-1 lineage, were used widely to produce the distemper vaccines in the 1950s, and these are the same vaccines used today.

Several recent reports suggest both the re-emergence and increased activity of CDV worldwide [20]. Cases of $\mathrm{CD}$ have also been reported this decade in vaccinated dogs in Japan [21], Mexico [22], Argentina [16], and the United States [23]. In each case, the strains associated with these cases have been shown to be genetically divergent from the vaccine lines. Respiratory and enteric signs associated with CD may be confused with those of other respiratory and enteric diseases, hindering early CDV diagnosis [24,25]. Therefore, rapid and accurate diagnosis of CDV infection would enable veterinarians to implement appropriate strategies in time to improve disease management and prevent outbreaks, particularly within a shelter environment.

Virus isolation has previously been difficult due to the lack of an efficient cell line. Engineered VERO cells have been developed to express the canine signaling lymphocyte activation molecule (SLAM; also known as CD150), which is one of the cellular receptors for canine distemper virus (CDV). These engineered cells show cytopathic effects around one day after inoculation and are highly sensitive for CDV isolation from canine hosts [26]. However, there is species-preference for the type of SLAM receptor [27], which has the potential to affect the ability to isolate the virus from certain non-carnivore hosts. Additionally, this method requires a cell culture system and is relatively expensive and labor intensive. CDV immunoassays for detection of CDV antigen, such as immunofluorescence staining and ELISA [28-32], in general are not sensitive enough to detect CDV in asymptomatic dogs or during acute CD infection [31]. Various conventional, nested, and real-time reverse transcription polymerase chain reaction (RT-PCR) assays, which offer high degrees of detection sensitivity and specificity, have also been developed for CDV [33-42]. However, requiring an experienced technician and a relatively expensive thermocycler, these assays have been applied to CDV diagnosis mostly in professional laboratories. As a result, a rapid, affordable, and user-friendly platform is still needed for early point-of-care (POC) detection of CDV infection.

Recently, insulated isothermal PCR (iiPCR), based on Rayleigh-Bénard convection PCR [43], has been shown to achieve relatively consistent and fast target amplification by convective PCR. The reaction is done in a copper ringwrapped capillary tube heated within a thermally baffled device, which is relatively simple and inexpensive $[44,45]$. In Rayleigh-Bénard convection PCR [43], spontaneous fluid convection in a cylindrical vessel is driven by temperature gradients that are formed simply by heating the vessel from the bottom at a fixed temperature. Reaction constituents are circulated sequentially through zones of temperature gradients to allow the denaturation, annealing, and extension steps of PCR to take place. Because each cycle is estimated to complete within a few seconds, detectable amounts of amplicons could be produced within $30 \mathrm{mi}-$ nutes. For iiPCR, the reaction is performed in a special capillary tube (namely $\mathrm{R}$-tube ${ }^{\mathrm{Tx}}$, Figure 1 ), which is wrapped with a copper ring near its base. This design facilitates fast and consistent heating of the fluid at the bottom end of capillary tubes. Furthermore, fluorescent hydrolysis probe technology was integrated into iiPCR to eliminate post-amplification analysis of amplicons [46]. POCKIT ${ }^{\mathrm{rm}}$ Nucleic Acid Analyzer (POCKIT ${ }^{\mathrm{rm}}$; GeneReach, Taichung City, Taiwan) is now available commercially to perform iiPCR/reverse transcription (RT)-iiPCR amplification, signal detection and data interpretation (Figure 1). Its temperature program allows single-tube RT-iiPCR. Fluorescent signals generated from fluorescent probe hydrolysis are detected and converted to digital signals by the optical and data processing modules integrated in the device. The built-in algorithms determine the signal-to-noise $(\mathrm{S} / \mathrm{N})$ ratio, i.e.

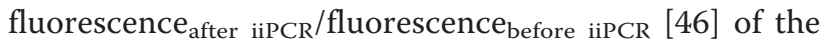
reaction and convert them automatically into simple readouts ("+", “-“, or "?") based on the default thresholds. The results are shown on the display screen within one hour. Validation of an iiPCR assay for white spot syndrome virus (WSSV), a shrimp DNA virus, demonstrated that this system could provide results with sensitivity and specificity comparable to those of a nested PCR assay within 1 hour for the detection of WSSV in shrimp samples [47].

Taking advantage of the hydrolysis probe-iiPCR method and the POCKIT ${ }^{\mathrm{mM}}$ device, the aim of this study was to develop a rapid, sensitive and specific method for CDV detection for points of care. The established CDV RT-iiPCR method was compared to a real-time RT-PCR [42] to evaluated its limit of detection as well as sensitivity and specificity for the detection of CDV in clinical specimens using 


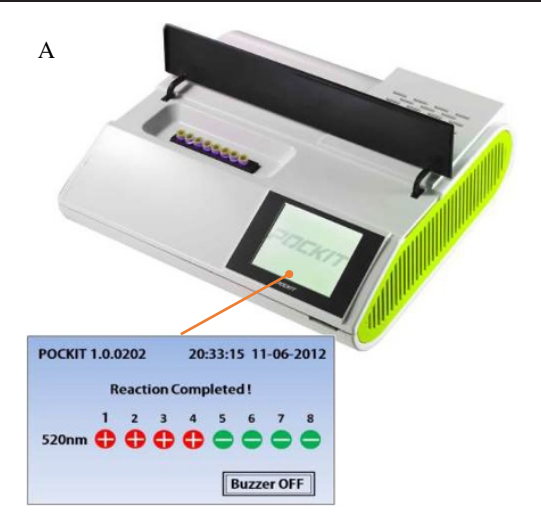

B

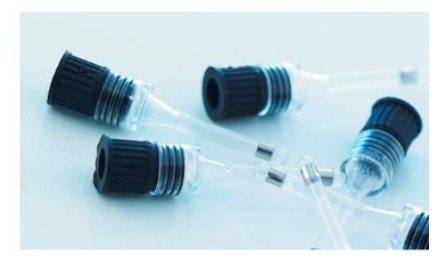

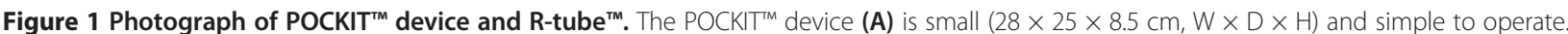
With a single default program, amplification and product detection steps of both iiPCR and RT-iiPCR could be completed on this device within 1 hour. One to eight reactions could be performed simultaneously in one run. Its simple user interface is accessible via a color touch screen. The reaction is carried out in a R-tube ${ }^{\text {TM }}(\mathbf{B})$, a capillary tube wrapped with a copper ring near its bottom end.

samples collected from dogs, raccoons, and foxes suspected to have CDV infection.

\section{Results \\ CDV RT-iiPCR sensitivity and specificity}

The percentage of positive results from in vitro transcribed RNA dilutions were 100\% (21/21), 100.0\% (21/21), 95\% $(20 / 21), 25.0 \%(4 / 16)$, and $0 \%(0 / 16)$ for $10^{3}, 10^{2}, 10^{1}, 10^{\circ}$, and $10^{-1}$ copies of the RNA standard, respectively. The $\geq 95 \%$ detection rate and $95 \%$ confidence limits, calculated by probit regression analysis, were 10.1 and 7.6-15.6 copies per reaction, respectively, indicating that the accuracy of the established reaction was comparable to that of the real-time RT-PCR for the detection of CDV.

Dilutions of the Onderstepoort reference strain, when tested with both real-time RT-PCR and RT-iiPCR, generated positive results with all $10^{-2}$ dilution samples. At the $10^{-3}$ dilution, $2 / 3$ and $1 / 2$ samples showed positive signals in RT-iiPCR and real-time RT-PCR, respectively (Table 1), indicating that the detection limit of RT-iiPCR was comparable to that of real-time RT-PCR.

During specificity testing, positive signals were generated only from CDV (Snyder Hill strain) but not from the other canine pathogens tested (Table 2), indicating that the established reaction could detect CDV specifically.

\section{Validation of CDV RT-iiPCR using clinical samples}

A clinical evaluation was further performed to determine whether the CDV RT-iiPCR was suitable for detection of CDV viruses from clinical samples. For this purpose, 110 clinical samples submitted to the University of Tennessee, College of Veterinary Medicine (UTCVM), Clinical Virology Lab from 2010 to 2014 were tested by RT-iiPCR and real-time RT-PCR. These samples included strains from 4 different clades of the phylogenetic trees derived from sequences of the $H$ gene and $M-F$ intergenic region [48]. $100 \%$ agreement was found between the two reactions (56 positive and 54 negative) (Table 3). No discrepancy was found in samples (13/56) containing low levels of CDV (Ct $>35$, real-time RTPCR, indicating that the established method reliably detects low amounts of CDV in clinical samples. Positive samples had real-time RT-PCR Ct values ranging from 14.31 to 39.41 , indicating that the RT-iiPCR was able to detect viral RNA across the entire range of the assay.

\section{Discussion}

In this report, aimed to improve point-of-care diagnosis of $\mathrm{CD}$, a novel one-tube RT-iiPCR method performed in a relatively simple field-deployable device, POCKIT ${ }^{\mathrm{mm}}$ Nucleic Acid Analyzer, was established for the detection of CDV in clinical samples. The results show that the RT-iiPCR was a sensitive and specific test to confirm CDV infection in dogs with detection limits comparable to that of the reference real-time RT-PCR.

Table 1 Comparison of analytical sensitivity between validated CDV real-time RT-PCR and RT-iiPCR using viral RNA of Onderstepoort strain

\begin{tabular}{|c|c|c|c|}
\hline \multirow{2}{*}{$\begin{array}{l}\text { Sample } \\
\text { dilution }\end{array}$} & \multicolumn{2}{|l|}{ Real-time RT-PCR } & \multirow{2}{*}{$\begin{array}{l}\text { RT-iiPCR No. } \\
\text { positive/total }\end{array}$} \\
\hline & No. positive/total & $\mathrm{Ct}$ & \\
\hline $\mathrm{NTC}^{*}$ & - & & - \\
\hline Positive control & + & & + \\
\hline $10^{-1}$ & $2 / 2$ & 34.09 & $3 / 3$ \\
\hline $10^{-2}$ & $2 / 2$ & 36.99 & $3 / 3$ \\
\hline $10^{-3}$ & $1 / 2$ & 40.2 & $2 / 3$ \\
\hline $10^{-4}$ & $0 / 2$ & & $0 / 3$ \\
\hline $10^{-5}$ & $0 / 2$ & & $0 / 3$ \\
\hline $10^{-6}$ & $0 / 2$ & & $0 / 3$ \\
\hline
\end{tabular}

*NTC-No template control. 
Table 2 Exclusivity analysis of CDV RT-iiPCR

\begin{tabular}{|c|c|c|c|c|}
\hline \multirow[t]{2}{*}{ Pathogen } & \multirow[t]{2}{*}{ Source } & \multicolumn{2}{|l|}{ RT-iiPCR } & \multirow{2}{*}{$\begin{array}{l}\text { Real-time } \\
\text { RT PCR (Ct) }\end{array}$} \\
\hline & & Results & $\mathrm{S} / \mathrm{N}$ & \\
\hline Canine distemper virus & Snyder Hill strain (ATCC) & + & 1.94 & 34.45 \\
\hline Bordetella bronchiseptica & Clinical sample* & - & 0.93 & Neg \\
\hline Canine herpesvirus & ATCC strain & - & 0.97 & Neg \\
\hline Canine respiratory coronavirus & Clinical sample* & - & 0.90 & Neg \\
\hline Canine parainfluenza virus & ATCC strain & - & 0.93 & Neg \\
\hline Canine adenovirus 2 & ATCC strain & - & 0.93 & Neg \\
\hline Canine parvovirus & Cornell strain & - & 0.94 & Neg \\
\hline Influenza virus H3N8 & Clinical sample* & - & 0.93 & Neg \\
\hline
\end{tabular}

*Pathogens obtained from clinical samples were previously cultured/isolated and validated by sequencing by the UTCVM Clinical Bacteriology and Virology Labs.

Molecular methods such as nested or real-time PCR assays require experienced technicians and costly equipment, limiting their application to professional laboratories. Moreover, the nested PCR assay is quite laborious and time-consuming and requires gel electrophoresis for amplicon detection, making it prone to cross contamination. Recently developed miniaturized chips have progressed by the introduction of microfluid technology for pathogen detection [49-51]. However, high costs of the reaction vessels and instruments, problems in product manufacturing, and sub-optimal detection methods have deferred these methods from being applied to point-ofcare diagnostics for resource-poor facilities.

In convective PCR, PCR cycling could be accomplished at high speeds using a single simple heater. Combining iiPCR and $5^{\prime}$ nuclease-based signal detection, automatically interpreted results of the established CDV reaction were generated within one hour in the POCKIT ${ }^{\mathrm{mm}}$ device. Hence, taking sample collection and nucleic acid extraction into account, the procedure could be completed within 1.5 hours. Both cDNA synthesis and PCR amplification are performed in a single step, eliminating the additional pipetting steps as well as minimizing the risks of contamination. Furthermore, different types of clinical samples (including swabs, urine, and tissues) were shown to be suitable sample types for CDV RT-iiPCR in this study. Purification of nucleic acids before PCR in general is required for successful target amplification because Taq DNA polymerase used in PCR is sensitive to inhibitors originating from samples and/or the purification processes

Table 3 Comparison of CDV RT-iiPCR versus CDV real-time RT-PCR for the detection of CDV in 110 samples

\begin{tabular}{lllll}
\hline & & \multicolumn{3}{l}{ Real-time RT-PCR } \\
\cline { 3 - 5 } & & Positive & Negative & Total \\
\hline RT-iiPCR & Positive & 56 & 0 & 56 \\
& Negative & 0 & 54 & 54 \\
& Total & 56 & 54 & 110 \\
\hline
\end{tabular}

[52]. Inhibitors often decrease assay sensitivity or even lead to false-negative results. For easy preparation of nucleic acids for CDV RT-iiPCR at POC settings, PetNAD ${ }^{\text {in }}$ Nucleic Acid Co-prep kit (GeneReach USA), a columnbased simple nucleic acid extraction method, is an option for whole blood, urine, oropharyngeal swab, conjunctival swab, and nasal swab samples.

The POCKIT $^{\mathrm{min}}$ system is a field portable device, which is enabled by its small size $(28 \times 25 \times 8.5 \mathrm{~cm}, \mathrm{~W} \times \mathrm{D} \times \mathrm{H})$, light weight $(2.1 \mathrm{~kg})$, and ruggedness. The device has passed the atmospheric preconditioning, atmospheric conditioning, compression, vibration, shock, and vibration tests specified in the International Safe Transit Association (ISTA) Procedure 2A 2011. Another important feature for the POCKIT ${ }^{\mathrm{mox}}$ device to be field deployable is that it could be operated with a rechargeable battery or car battery, allowing application of this system in low resource settings with unstable electricity supply. Furthermore, working in a lyophilized format, the reagents could be shipped and stored without the need for refrigeration.

CDV is not a zoonotic pathogen and pathological waste in general could be placed in a plastic bag to be disposed of as regular solid waste (www.epa.state.oh.us/dsiwm). Furthermore, disposables (such as R-tube ${ }^{\mathrm{m}}$, Eppendorf tubes, and micropipette tips) used in the RT-iiPCR/ POCKIT $^{\mathrm{Tw}}$ tests are of small sizes. Therefore, for tests performed outside of the office/laboratory, infectious wastes generated from this test could be packed with double leakproof plastic bags or biohazard bags to be treated locally or taken back to the office/laboratory for disposal. The disposal should follow the current Biosafety guidelines.

Instead of sending specimens to a diagnostic laboratory, on-site diagnosis of CDV infection could eliminate shipping and processing costs and shorten test turn-around time significantly to improve disease management. For canine infectious respiratory disease in shelters and boarding kennel environments, this would allow appropriate quarantine and management of infected dogs. Additionally, this method identifies a conserved region of the genome 
and was used to successfully detect CDV in tissues from raccoons and foxes in this study. Therefore, the established method could be utilized potentially in the field for CDV surveillance in wildlife populations.

\section{Conclusions}

In summary, the novel features of the CDV RT-iiPCR with POCKIT ${ }^{\mathrm{max}}$ method enabled automatic result interpretation of CDV RNA detection in a portable device with sensitivity and specificity comparable to real-time RT-PCR. This field-deployable assay could serve as a useful tool for point-of-care needs in CDV diagnosis and surveillance.

\section{Methods}

\section{Samples}

Reference strains used included the Snyder Hill strain (ATCC, Manassas, VA, USA), an isolate from the brain of a dog in Ithaca, New York, in 1950s and the Onderstepoort strain, originating from a disease outbreak among North American ranched foxes in the 1930s.

Clinical samples used were samples submitted to the UTCVM Clinical Virology Lab between 2010 and 2014 for real-time RT-PCR analysis for CDV. Submissions were mainly from eastern Tennessee, but samples from Canada, Texas, Washington, Kentucky, West Virginia, Virginia, South Carolina, and Pennsylvania were also tested. Most samples were from dogs (including nasal/oropharyngeal swabs and urine), but tissues from raccoons and foxes were also included. These samples were diagnostic samples submitted to the lab for routine testing and not collected specifically from research animals for research purposes; therefore, this was exempt from requiring Institutional Animal Care and Use Committee approval.

\section{RNA extraction}

RNA was extracted from clinical samples (including nasopharyngeal/conjunctival swabs, urine, and tissues) and dilutions of reference strains with the QIAamp viral RNA kit (Qiagen, Valencia, CA, USA) according to the manufacturer's instructions. Tissues were macerated with an equal volume of PBS in a Stomacher (Tekmar Company, Cincinnati, OH, USA) and supernatant was used for extraction. Samples previously extracted were stored at $-80^{\circ} \mathrm{C}$.

\section{Plasmid construction and standard RNA preparation}

To generate the standard template (pT-CDV), a 1463-bp partial cDNA sequence of the nucleocapsid $(N)$ gene amplified by RT-PCR (primers CDV F1 and CDV R1463, Table 4) was cloned into the pCR2.1TOPO vector (Invitrogen, Carlsbad, CA). Calculation of copy number was based on the concentrations determined by a DU730 spectrophotometer (Beckman Coulter, Brea, CA, USA). Dilutions of standard DNA were prepared in TE buffer (10 mM Tris- $\mathrm{HCl}$ and $1 \mathrm{mM}$ EDTA, $\mathrm{pH}$ 8.0) containing $30 \mathrm{ng} / \mu \mathrm{l}$ tRNA from Escherichia coli (Sigma-Aldrich, Milan, Italy) and stored at $-20^{\circ} \mathrm{C}$. To prepare the RNA standards, HindIII-linearized pT-CDV plasmid was subjected to in vitro transcription using the MEGAscript T7 Kit (Ambion, Huntingdon, UK). RNA transcripts were produced, treated with DNase I, and purified by $\mathrm{LiCl}$ precipitation by following the manufacturer's instruction. Copy numbers of RNA transcripts were calculated based on concentrations determined by a spectrophotometer. Dilutions of RNA were prepared in TE buffer containing $30 \mathrm{ng} / \mu \mathrm{l} \mathrm{tRNA}$. Aliquots were frozen at $-70^{\circ} \mathrm{C}$ and used only once.

\section{CDV real-time RT-PCR}

RNA samples were tested in the UTCVM Clinical Virology Lab by real-time RT-PCR using the primers and probe designed by Elia et al. [42] (Table 4). Briefly, the SuperScript III Platinum One-Step qRT-PCR Kit (Invitrogen, Life Technologies, Grand Island, NY, USA) was used with $300 \mathrm{nM}$ of each primer and $200 \mathrm{nM}$ of probe in a $25 \mu \mathrm{L}$ total volume reaction with $5 \mu \mathrm{L}$ RNA. Amplification was carried out in a Smart Cycler II (Cepheid, Sunnyvale, CA, USA) with an initial RT step of $42^{\circ} \mathrm{C}$ for $30 \mathrm{~min}$., followed by $95^{\circ} \mathrm{C}$ for $2 \mathrm{~min}$., and 45 cycles of $95^{\circ} \mathrm{C}$ for 15 sec., $48^{\circ} \mathrm{C}$ for $1 \mathrm{~min}$. and $60^{\circ} \mathrm{C}$ for $1 \mathrm{~min}$.

Table 4 Primers and probes used in cloning, CDV RT-iiPCR and real-time RT-PCR

\begin{tabular}{|c|c|c|}
\hline Primer & Nucleotide sequence $\left(5^{\prime}-3^{\prime}\right)$ & Note* \\
\hline CDV-F & AGCTAGTTTCATCTTAACTATCAAATT & CDV real-time RT-PCR forward primer ${ }^{\mathrm{a}}$ \\
\hline CDV-R & TTAACTCTCCAGAAAACTCATGC & CDV real-time RT-PCR reverse primer ${ }^{\mathrm{a}}$ \\
\hline CDV-P & FAM-ACCCAAGAGCCGGATACATAGTTTCAATGC-BHQ1 & CDV real-time RT-PCR probe ${ }^{a}$ \\
\hline CDV-F1 & ATGGCTAGCCTTCTTAAAAGCCTCACA & CDV cloning primer (nt108-134)* \\
\hline CDV-R1 & TTCCGATCATCGTCATTTCCATCA & CDV cloning primer (nt1570-1547)* \\
\hline CDViiF & CCGGAAATCAACGGACCTAAATT & CDV RT-iiPCR primer $(n t 291 \sim 313)^{*}$ \\
\hline CDViiR & GTCGTCTATGATCCTCTGGATCAA & CDV RT-iiPCR primer (nt389 366)* \\
\hline CDViiP & FAM-CAGTATCCTCTCCTTGTTCGTGGA-MGB-NFQ & CDV RT-iiPCR probe (nt329 352)* \\
\hline
\end{tabular}

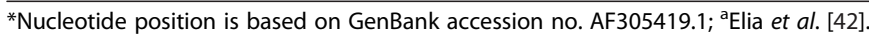




\section{RT-iiPCR}

The CDV RT-iiPCR was designed on the basis of the hydrolysis probe-based POCKIT ${ }^{\mathrm{ma}}$ method described previously [46]. The CDV-specific RT-iiPCR primers (Table 4) were designed on the basis of $90 \mathrm{CDV} N$ sequences available in GenBank. These sequences included strains collected from dogs, wolves (GenBank accession no. KF914669.1), foxes (GenBank accession no. JX681125, EU489475.1, EF445056.1, EF445050.1, FJ710174.1, and HQ540293.1), and mink (GenBank accession no. EU375802.1). The $N$ gene contains conserved sequences with the highest homology within the genomic RNA of CDV. Primer and probe pairs were designed according to the recommended principles for iiPCR (http:// www.iipcr.com/eweb/uploadfile/20130522114104277.pdf). Amplicons with major secondary structures were excluded, based on prediction made by the MFold program (http://mfold.rna.albany.edu/?q=mfold). The probe was labeled with fluorescent reporter dye 6-carboxyfluorescein (FAM) at the $5^{\prime}$ end and a minor groove binder group (MGB) with a non-fluorescent quencher (NFQ) at the 3' end (Applied Biosystems) (Table 4). The MGB group increased the stability and specificity of probe hybridization [53]. Annealing temperature of the probe was approximately $10^{\circ} \mathrm{C}$ higher than those of the iiPCR primers. The expected size of the amplicon was $99 \mathrm{bp}$. Components of the iiPCR reaction were optimized and the final master mix included the following: forward primer CDViiF, reverse primer CDViiR, probe CDViiP, dNTP, Taq DNA polymerase, MMLV reverse transcriptase, $50 \mathrm{mM}$ Tris$\mathrm{HCl}$ (pH 8.3), $75 \mathrm{mM} \mathrm{KCl}, 3 \mathrm{mM} \mathrm{MgCl}$, and $1 \mathrm{mM} \mathrm{DTT}$. These components were lyophilized. The lyophilized reagent was rehydrated with $50 \mu \mathrm{L}$ of Reconstitution Buffer (GeneReach USA) before $5 \mu \mathrm{L}$ of the nucleic acid sample was added to the mixture. Subsequently, $50 \mu \mathrm{L}$ of the final mixture was transferred to an R-tube ${ }^{\text {tw }}$ (GeneReach USA), which was spun briefly in a cubee ${ }^{\text {Tw }}$ mini centrifuge (GeneReach USA) and placed into the reaction chamber of POCKIT $^{\text {Tw }}$ Nucleic Acid Analyzer. The reaction completed in less than one hour and showed the results on the display screen. Using an optical detection module similar to a previously described iiPCR device [46], POCKIT ${ }^{\mathrm{mm}}$ collects optical signals through an integrated circuits controllerregulated sensor. The collected fluorescent signal-to-noise ratios ( signal $_{\text {after }} /$ signal $_{\text {before }}$ ) were converted to positive (+symbol), negative (- symbol), and indeterminate (? symbol) according to the default $\mathrm{S} / \mathrm{N}$ thresholds $[44,46]$. A "?" result indicated that the signals were ambiguous and the sample should be tested again.

\section{RT-iiPCR sensitivity and specificity}

Analytical sensitivity of the final CDV RT-iiPCR was determined by using 10-fold serial dilutions of in vitro transcribed RNA. Each dilution of the in vitro transcribed
RNA was tested 16 or 21 times. To further evaluate the sensitivity of the CDV RT-iiPCR, triplicates of 10 -fold serial dilutions of CDV Onderstepoort strain were subjected to RNA extraction and analyzed by RT-iiPCR and the reference real-time RT-PCR in parallel.

To evaluate specificity of CDV RT-iiPCR, nucleic acid extracts of common canine respiratory pathogens, including Bordetella bronchiseptica, canine parvovirus, canine herpesvirus, canine adenovirus 2, canine influenza virus (subtype H3N8), canine parainfluenza virus, and canine respiratory coronavirus, were subjected to CDV RT-iiPCR analysis. RNA extracted from the Snyder Hill reference strain was used as a positive control in this experiment.

\section{Abbreviations}

CD: Canine distemper; CDV: Canine distemper virus; FAM: 6-carboxyfluorescein; iiPCR: Insulated isothermal PCR; MGB: Minor groove binder group; NFQ: Non-fluorescent quencher; RT-iiPCR: Revers transcription-insulated isothermal PCR; S/N: Signal-to-noise ratio; UTCVM: University of Tennessee College of Veterinary Medicine.

\section{Competing interests}

RPW declares no competing interests. FCL, YLT, PYL, HFGC, HTTW are affiliated to GeneReach USA. However, this does not alter our adherence to all the BMC Veterinary Research policies on sharing data and materials.

\section{Authors' contributions}

RPW participated in experimental design, data analysis and the writing of the manuscript. FCL performed the experimental design and the experiments, and participated in the writing of the manuscript. YLT performed the study design, data analysis and validation experiments. PYL participated in the study design, data analysis and the writing of the manuscript. HFGC and HTTW coordinated the study and participated in the data analysis and writing of the manuscript. All authors read and approved the final manuscript.

\section{Acknowledgments}

The authors thank Matt Riley, Elena Sanchez, and Sarah Elliott from the Department of Biomedical and Diagnostic Sciences, University of Tennessee for their technical assistance.

\section{Author details}

'University of Tennessee College of Veterinary Medicine Clinical Virology Lab, Department of Biomedical and Diagnostic Sciences, University of Tennessee, 2407 River Dr, Rm A205, Knoxville, TN 37996, USA. ${ }^{2}$ GeneReach USA, Lexington, MA, USA.

Received: 21 June 2014 Accepted: 1 September 2014 Published online: 09 September 2014

\section{References}

1. Carpenter MA, Appel MJ, Roelke-Parker ME, Munson L, Hofer H, East M, O'Brien SJ: Genetic characterization of canine distemper virus in Serengeti carnivores. Vet Immunol Immunopathol 1998, 65:259-266.

2. Kapil S, Yeary TJ: Canine distemper spillover in domestic dogs from urban wildlife. Vet Clin North Am Small Anim Pract 2011, 41:1069-1086.

3. Seimon TA, Miquelle DG, Chang TY, Newton AL, Korotkova I, Ivanchuk G, Lyubchenko E, Tupikov A, Slabe E, McAloose D: Canine distemper virus: an emerging disease in wild endangered Amur tigers (Panthera tigris altaica). MBio 2013, 4(4):doi:10.1128/mBio.00410-13.

4. Wisely SM, Buskirk SW, Fleming MA, McDonald DB, Ostrander EA: Genetic diversity and fitness in black-footed ferrets before and during a bottleneck. J Hered 2002, 93:231-237.

5. Roelke-Parker ME, Munson L, Packer C, Kock R, Cleaveland S, Carpenter M, O'Brien SJ, Pospischil A, Hofmann-Lehmann R, Lutz H, Mwamengele GL, Mgasa MN, Machange GA, Summers BA, Appel MJ: A canine distemper virus epidemic in Serengeti lions (Panthera leo). Nature 1996, 379:441-445. 
6. Appel MJ, Reggiardo C, Summers BA, Pearce-Kelling S, Mare CJ, Noon TH, Reed RE, Shively JN, Orvell C: Canine distemper virus infection and encephalitis in javelinas (collared peccaries). Arch Virol 1991, 119:147-152

7. Sakai K, Nagata N, Ami Y, Seki F, Suzaki Y, Iwata-Yoshikawa N, Suzuki T, Fukushi S, Mizutani T, Yoshikawa T, Otsuki N, Kurane I, Komase K, Yamaguchi R, Haseqawa H, Saijo M, Takeda M, Morikawa S: Lethal canine distemper virus outbreak in cynomolgus monkeys in Japan in 2008. J Virol 2013, 87:1105-1114.

8. Sun Z, Li A, Ye H, Shi Y, Hu Z, Zeng L: Natural infection with canine distemper virus in hand-feeding Rhesus monkeys in China. Vet Microbiol 2010, 141:374-378.

9. Lednicky JA, Dubach J, Kinsel MJ, Meehan TP, Bocchetta M, Hungerford LL, Sarich NA, Witechki KE, Braid MD, Pedrak C, Houde CM: Genetically distant American canine distemper virus lineages have recently caused epizootics with somewhat different characteristics in raccoons living around a large suburban zoo in the USA. Virol J 2004, 1:2.

10. Wilson SC, Eybatov TM, Amano M, Jepson PD, Goodman SJ: The role of canine distemper virus and persistent organic pollutants in mortality patterns of Caspian seals (Pusa caspica). PLoS One 2014, 9(7):e99265.

11. Baumgartner W, Orvell C, Reinacher M: Naturally occurring canine distemper virus encephalitis: distribution and expression of viral polypeptides in nervous tissues. Acta Neuropathol 1989, 78:504-512.

12. Martella V, Elia G, Buonavoglia C: Canine distemper virus. Vet Clin N Am Small Anim Pract 2008, 38:787-797.

13. Woma TY, van Vuuren M, Bosman AM, Quan M, Oosthuizen M: Phylogenetic analysis of the haemagglutinin gene of current wild-type canine distemper viruses from South Africa: lineage Africa. Vet Microbiol 2010, 143:126-132

14. Zhao JJ, Yan XJ, Chai XL, Martella V, Luo GL, Zhang HL, Gao H, Liu YX, Bai X, Zhang L, Chen T, Xu L, Zhao CF, Wang FX, Shao XQ, Wu W, Cheng SP: Phylogenetic analysis of the haemagglutinin gene of canine distemper virus strains detected from breeding foxes, raccoon dogs and minks in China. Vet Microbiol 2010, 140:34-42.

15. Radtanakatikanon A, Keawcharoen J, Charoenvisal NT, Poovorawan Y, Prompetchara E, Yamaguchi R, Techangamsuwan S: Genotypic lineages and restriction fragment length polymorphism of canine distemper virus isolates in Thailand. Vet Microbiol 2013, 166:76-83.

16. Calderon MG, Remorini P, Periolo O, Iglesias M, Mattion N, La Torre J: Detection by RT-PCR and genetic characterization of canine distemper virus from vaccinated and non-vaccinated dogs in Argentina. Vet Microbiol 2007, 125:341-349.

17. Sarute N, Perez R, Aldaz J, Alfieri AA, Alfieri AF, Name D, Llanes J, Hernandez $M$, Francia L, Panzera Y: Molecular typing of canine distemper virus strains reveals the presence of a new genetic variant in South America. Virus Genes 2014, 48:474-478

18. Budaszewski Rda F, Pinto LD, Weber MN, Caldart ET, Alves CD, Martella V, Ikuta N, Lunge VR, Canal CW: Genotyping of canine distemper virus strains circulating in Brazil from 2008 to 2012. Virus Res 2014, 180:76-83.

19. Espinal MA, Díaz FJ, Ruiz-Saenz J: Phylogenetic evidence of a new canine distemper virus lineage among domestic dogs in Colombia, South America. Vet Microbiol 2014, 172:168-176.

20. Bolt G, Jensen TD, Gottschalck E, Arctander P, Appel MJ, Buckland R, Blixenkrone-Moller M: Genetic diversity of the attachment $(H)$ protein gene of current field isolates of canine distemper virus. J Gen Virol 1997, 78(Pt 2):367-372.

21. Lan NT, Yamaguchi R, Inomata A, Furuya Y, Uchida K, Sugano S, Tateyama S: Comparative analyses of canine distemper viral isolates from clinical cases of canine distemper in vaccinated dogs. Vet Microbio/ 2006, 115:32-42.

22. Simon-Martinez J, Ulloa-Arvizu R, Soriano VE, Fajardo R: Identification of a genetic variant of canine distemper virus from clinical cases in two vaccinated dogs in Mexico. Vet J 2008, 175:423-426.

23. Kapil S, Allison RW, Johnston L 3rd, Murray BL, Holland S, Meinkoth J, Johnson B: Canine distemper virus strains circulating among North American dogs. Clin Vaccine Immunol 2008, 15:707-712.

24. Appel MJ: Distemper pathogenesis in dogs. J Am Vet Med Assoc 1970, 156:1681-1684.

25. Griot $C$, Vandevelde $M$, Schobesberger M, Zurbriggen A: Canine distemper, a re-emerging morbillivirus with complex neuropathogenic mechanisms. Anim Health Res Rev 2003, 4:1-10.

26. Seki F, Ono N, Yamaguchi R, Yanagi Y: Efficient isolation of wild strains of canine distemper virus in Vero cells expressing canine SLAM (CD150) and their adaptability to marmoset B95a cells. J Virol 2003, 77:9943-9950.
27. Nikolin VM, Osterrieder K, von Messling V, Hofer H, Anderson D, Dubovi E, Brunner E, East ML: Antagonistic pleiotropy and fitness trade-offs reveal specialist and generalist traits in strains of canine distemper virus. PLoS One 2012, 7(12):e50955.

28. Li Z, Zhang Y, Wang H, Jin J, Li W: Sandwich-dot enzyme-linked immunosorbent assay for the detection of canine distemper virus. Can J Vet Res 2013, 77:303-308.

29. Liang CT, Chueh LL, Pang VF, Zhuo YX, Liang SC, Yu CK, Chiang H, Lee CC, Liu CH: A non-biotin polymerized horseradish-peroxidase method for the immunohistochemical diagnosis of canine distemper. J Comp Pathol 2007, 136:57-64

30. Jozwik A, Frymus T: Comparison of the immunofluorescence assay with RT-PCR and nested PCR in the diagnosis of canine distemper. Vet Res Commun 2005, 29:347-359.

31. von Messling V, Harder TC, Moennig V, Rautenberg P, Nolte I, Haas L: Rapid and sensitive detection of immunoglobulin $\mathrm{M}(\mathrm{Ig} \mathrm{M})$ and $\lg \mathrm{G}$ antibodies against canine distemper virus by a new recombinant nucleocapsid protein-based enzyme-linked immunosorbent assay. J Clin Microbiol 1999, 37:1049-1056.

32. Blixenkrone-Moller M, Pedersen IR, Appel MJ, Griot C: Detection of IgM antibodies against canine distemper virus in dog and mink sera employing enzyme-linked immunosorbent assay (ELISA). J Vet Diagn Invest 1991, 3:3-9.

33. Amude AM, Alfieri AA, Alfieri AF: Antemortem diagnosis of CDV infection by RT-PCR in distemper dogs with neurological deficits without the typical clinical presentation. Vet Res Commun 2006, 30:679-687.

34. Frisk AL, Konig M, Moritz A, Baumgartner W: Detection of canine distemper virus nucleoprotein RNA by reverse transcription-PCR using serum, whole blood, and cerebrospinal fluid from dogs with distemper. J Clin Microbiol 1999, 37:3634-3643.

35. Rzezutka A, Mizak B: Application of N-PCR for diagnosis of distemper in dogs and fur animals. Vet Microbiol 2002, 88:95-103.

36. Saito TB, Alfieri AA, Wosiacki SR, Negrao FJ, Morais HS, Alfieri AF: Detection of canine distemper virus by reverse transcriptase-polymerase chain reaction in the urine of dogs with clinical signs of distemper encephalitis. Res Vet Sci 2006, 80:116-119.

37. Shin Y, Mori T, Okita M, Gemma T, Kai C, Mikami T: Detection of canine distemper virus nucleocapsid protein gene in canine peripheral blood mononuclear cells by RT-PCR. J Vet Med Sci 1995, 57:439-445.

38. Shin YJ, Cho KO, Cho HS, Kang SK, Kim HJ, Kim YH, Park HS, Park NY: Comparison of one-step RT-PCR and a nested PCR for the detection of canine distemper virus in clinical samples. Aust Vet J 2004, 82:83-86.

39. Gizzi AB, Oliveira ST, Leutenegger CM, Estrada M, Kozemjakin DA, Stedile R, Marcondes M, Biondo AW: Presence of infectious agents and co-infections in diarrheic dogs determined with a real-time polymerase chain reaction-based panel. BMC Vet Res 2014, 10:23.

40. Negrao FJ, Gardinali NR, Headley SA, Alfieri AA, Fernandez MA, Alfieri AF: Phylogenetic analyses of the hemagglutinin gene of wild-type strains of canine distemper virus in southern Brazil. Genet Mol Res 2013, 12:2549-2555.

41. Jeoung HY, Song DS, Jeong WS, Lee WH, Song JY, An DJ: Simultaneous detection of canine respiratory disease associated viruses by a multiplex reverse transcription-polymerase chain reaction assay. J Vet Med Sci 2012, 75:103-106.

42. Elia G, Decaro N, Martella V, Cirone F, Lucente MS, Lorusso E, Di Trani L, Elia G, Decaro N, Martella V, Cirone F, Lucente MS, Lorusso E, Di Trani L, Buonavoglia C: Detection of canine distemper virus in dogs by real-time RT-PCR. J Virol Methods 2006, 136:171-176.

43. Krishnan M, Ugaz VM, Burns MA: PCR in a Rayleigh-Benard convection cell. Science 2002, 298:793.

44. Chang HFG, Tsai YL, Tsai CF, Lin CK, Lee PY, Teng PH, Su C, Jeng CC: A thermally baffled device for highly stabilized convective PCR. Biotech J 2012, doi:10.1002/biot.201100453.

45. Tsai YL, Lin YC, Chou PH, Teng PH, Lee PY: Detection of white spot syndrome virus by polymerase chain reaction performed under insulated isothermal conditions. J Virol Methods 2012, 181:134-137.

46. Tsai YL, Wang HT, Chang HF, Tsai CF, Lin CK, Teng PH, Su C, Jeng CC, Lee PY: Development of TaqMan probe-based insulated isothermal PCR (iiPCR) for sensitive and specific on-site pathogen detection. PLOS One 2012, 7(9):e45278.

47. Tsai YL, Wang HC, Lo CF, Tang-Nelson K, Lightner D, Ou BR, Hour AL, Tsai CF, Yen CC, Chang HF, Teng PH, Lee PY: Validation of a commercial 
insulated isothermal PCR-based POCKIT test for rapid and easy detection of white spot syndrome virus infection in Litopenaeus vannamei. PLoS One 2014, 9(3):e90545

48. Wilkes RP, Sanchez E, Riley MC, Kennedy MA: Real-time reverse transcription polymerase chain reaction method for detection of Canine distemper virus modified live vaccine shedding for differentiation from infection with wild-type strains. J Vet Diagn Invest 2014, 26:27-34.

49. Ritzi-Lehnert M: Development of chip-compatible sample preparation for diagnosis of infectious diseases. Expert Rev Mol Diagn 2012, 12:189-206.

50. Wu J, Kodzius R, Cao W, Wen W: Extraction, amplification and detection of DNA in microfluidic chip-based assays. Microchim Acta 2013, doi:10.1007/ s00604-013-1 140-2.

51. Jayamohan H, Sant HJ, Gale BK: Applications of microfluidics for molecular diagnostics. Methods Mol Biol 2013, 949:305-334.

52. Schrader C, Schielke A, Ellerbroek L, Johne R: PCR inhibitors - occurrence, properties and removal. J Appl Microbiol 2012, 113:1014-1026.

53. Kutyavin IV, Afonina IA, Mills A, Gorn W, Lukhtanov EA, Belousov ES, Singer MJ, Walburger DK, Lokhov SG, Gall AA, Dempcy R, Reed MW, Meyer RB, Hedqpeth $\mathrm{J}$ : 3'-minor groove binder-DNA probes increase sequence specificity at PCR extension temperatures. Nucleic Acids Res 2000, 28:655-661.

doi:10.1186/s12917-014-0213-8

Cite this article as: Wilkes et al.: Rapid and sensitive detection of canine distemper virus by one-tube reverse transcription-insulated isothermal polymerase chain reaction. BMC Veterinany Research 2014 10:213.

\section{Submit your next manuscript to BioMed Central and take full advantage of:}

- Convenient online submission

- Thorough peer review

- No space constraints or color figure charges

- Immediate publication on acceptance

- Inclusion in PubMed, CAS, Scopus and Google Scholar

- Research which is freely available for redistribution 